Marquette University

e-Publications@Marquette

Philosophy Faculty Research and Publications

Philosophy, Department of

6-1-1979

\title{
What is Living and What is Dead in Hegel, Today?
}

Howard P. Kainz

Marquette University, howard.kainz@marquette.edu

Accepted version. The Owl of Minerva, Vol. 10, No. 4 (June 1979): 1-5. DOI. (C) 1979 Philosophy Documentation Center. Used with permission. 
Marquette University

e-Publications@Marquette

\title{
Philosophy Faculty Research and Publications/ Department of Philosophy
}

\author{
This paper is NOT THE PUBLI SHED VERSION; but the author's final, \\ peer-reviewed manuscript. The published version may be accessed by \\ following the link in the citation below.
}

The Owl of Minerva, Vol. 10, No. 4 (June 1979): 1-5. DOI. This article is $($ ) Philosophy Documentation Center and permission has been granted for this version to appear in e-Publications@Marquette. Philosophy Documentation Center does not grant permission for this article to be further copied/distributed or hosted elsewhere without the express permission from Philosophy Documentation Center.

\section{WHAT IS LIVING AND WHAT IS DEAD IN HEGEL, TODAY?}

First of all, I should perhaps apologize for purloining the title of a book by Benedetto Croce and affixing it to the much more modest effort in this final chapter. However, the addition of the adverb, "today," at the end of the title, serves to differentiate my paper from Croce's book, at the same time as it gives an indication of the affinity of my enterprise with Croce's - namely, an updating and critical reassessment of Hegel and Hegelianism.

Croce in his 1907 book on Hegel came to the conclusion that the weak point in Hegel's system was Hegel's "panlogism," that "exrescence of Hegel's System" through which the dualism of Nature and Spirit was smothered; or, to say the same thing in a different way, the unjustified and unjustifiable passage from one distinct and irreducible reality, the "Idea", to another distinct and irreducible reality, Nature. Croce also defended Hegel, however, and thought that Hegel's most important contribution was - in contrast to Bergson and others who would like to renounce thought for intuition -"to have demonstrated that the requirement of a concrete consciousness was fulfilled in the form of thinking." Croce also indulged himself in the psychoanalytic insight that the hate of Schopenhauer, Janet and other I9th century adversaries of Hegel was motivated by the fact that they saw Hegel as the symbol of philosophy itself, "which is without heart or compassion for feeble-hearted and lazy thinkers, and which does not allow itself to be seduced by the evils of sentiment or imagination, or to be satiated with offerings of light appetizers from a half-baked science."

Whatever strong and weak points Hegel may have, apparently his appeal has not 
diminished in our present era, and in fact some are speaking of a "Hegel Renaissance". One phenomenon that would lead one to believe there is such a renaissance in progress, is the tremendous outpouring of writings on Hegel in the last 5 or 6 years. In collaboration with Thomas Lutzow I have just completed a review article of almost 40 books on Hegel published since $1972 .{ }^{1}$ One section of this review is devoted to work on Hegel's Phenomenology, and I might refer to this section of the review as a dramatic example of the volume of work done on Hegel lately. In this section, we discuss nine English-language books published since 1972, including 7 commentaries. ${ }^{2}$ Since only two books specifically on the Phenomenology were published in English during the preceding century, ${ }^{3}$ one would perhaps be justified in concluding that something like a renaissance (if not mass delusion) was taking place in Hegel studies.

What is the cause of this revival of interest in Hegel? Some of the more obvious causes are well-known: The necessity for understanding Hegel to assess Kierkegaard's reaction against Hegel, and to assess Marx's and Sartre's use of Hegelian concepts in developing their own respective positions. For some, the interest in Hegel is concomitant with a reaction against analytic philosophy. ${ }^{4}$ For others, the movement to Hegel may be an outgrowth of analytic philosophy itself. Richard Bernstein broaches this latter possibility in a recent article, ${ }^{5}$ in which he argues that analytical philosophers are finding more and more that single and discrete analyses "spill over to other issues" (as happens in Hegel's analyses), that progress on epistemological issues requires confrontation with metaphysical issues (a requirement that Hegel insisted on), that one can't deal effectively with reference and denotation without getting into ontology (another Hegelian insight), and so forth. ${ }^{6}$ Bernstein finds another source for renewed interest in Hegel in developments within the philosophy of science - e.g. new theories about the evolution of scientific paradigms, and recent recognition of the influence of social

\footnotetext{
${ }^{1}$ See "Recent Works on Hegel", forthcoming in the American Philosophical Quarterly, Jan., 1979.

${ }^{2}$ Hyppolite, Genesis and structure of the Phenomenology of Spirit of Hegel (Evanston, 111., 1974); Navickas, Consciousness and Reality: Hegel's Philosophy of Subjectivity (The Hague, 1976); Marx, W., Hegel's "Phenomenology of Spirit": its Point and Purpose - A Commentary on the Preface and Introduction (N.Y., 1975); Robinson, J., Duty and Hyprocrisy in Hegel s "Phenomenology of Mind": An Essay in the Real and the Ideal (Toronto, 1977); Lauer, A Reading of Hegel's ' Phenomenology of Spirit" (N.Y., 1976); Kainz, H., Hegel's Phenomenology of spirit, Part I: Analysis Independence: A Study of the Political Ideas of Hegel's"Phenomenology of Mind" (Cambridge, 1976); Norman, R., Hegel's Phenomenology: A Philosophical Introduction (N.Y. 1976); Miller (tr) and Findlay, J. Phenomenology of Spirit (Oxford, 1977).

${ }^{3}$ Loewenberg's Hegel's Phenomenology: Dialogues in the Life of Mind (1965) and the Nichols translation of Kojeve's Introduction to the Reading of Hegel (1969).

${ }^{4}$ An example of this reaction is to be found in Richard Norman's Hegel's Phenomenology, which is one volume in the "Philosophy Now" series, a series which is described by the publisher (St. Martin's Press) as "books...united by nothing except discontent with the narrowness and specialism of analytic philosophy. Convinced that the analytical movement has spent its momentum, its latest phase no doubt its last, the [Philosophy Now] series seeks in one way or another to push philosophy out of its ivory tower."

5"Why Hegel Now", in The Review of Metaphysics, XXXI, 1, Sept. 1977.

${ }^{6}$ Ibid., p. 44
} 
contexts on scientific theories. ${ }^{7}$ Bernstein even conjectures, with Wilfred Sellars, that the interest of the logical positivists and logical atomists in Hume, and of the conceptual analysts in Kant, may soon be followed by a "Hegelian 'trip' " on the part of avant garde analysts in our own day.

I would like to add the following putative causes to the ones cited by Bernstein: First of all, the idea of a perennial philosophy, espoused by thinkers as diverse as Leibniz and Peirce, and revived by Mortimer Adler and associates, seems itself to be perennial, whether or not philosophy is perennial. Adler a few decades ago looked to scholastic realism as an anchor of sanity in a philosophical world gone astray in sectarian rivalry and undisciplined individualism. But the synthesizing power of the great scholastic edifice has proven not to be unlimited. For those still seeking a perennial philosophy, but disenchanted with the scholastic model, Hegel may seem an improvement, if not the final solution. For Hegel saw all philosophical schools and systems as the unfolding of one central problematic - the relationship of being to thought - and also manages to synthesize the "Transcendental turn" into this overall schema (something that scholastic realism was constitutionally unable to accomplish). But alas, the synthesizing power of the Hegelian system is proving itself to be also finite in an intellectual world grown accustomed to evolution, relativity, the demise of monarchical political systems, the decline of the West, and multi-valued logics.

Perhaps a more important rallying point with regard to current attention to Hegel is the resurgence of interest in the history of philosophy as an essential pursuit of philosophy, as well as an essentially philosophical pursuit. This renewed interest in history may quite conceivably have been brought about by the very pluralism and factionalism found in contemporary philosophy (much in the same fashion that a society in times of confusion or anarchy may grapple after stability by studying its own historical roots and heritage). Those who would search in the history of philosophy to find some illumination about the essential goings-on in contemporary philosophy, will find a kindred spirit in G.W.F. Hegel, who perhaps more than any other philosopher emphasized philosophy's history and in a very real sense even identified philosophy with its history.

I mentioned above that in Croce's estimation Hegel was the symbolic personification of philosophy for many of his anti-philosophical or anti-intellectual enemies. In our own time, the reason why many are attracted to Hegel may be that they see him as the symbol of philosophy - or, more specifically, of that old-style philosophy which openly and unabashedly announced that it was concerned with "knowing all things" in some sort of ultimate way. Nowadays, if anyone has philosophical inclinations of this sort, he is best advised to keep silent about them. Because, after all, philosophy, following the example of science, has become extremely specialized and compartmentalized, and in these days of the neverending "knowledge-

${ }^{7}$ Ibid., p. 39. 
explosion" who would seriously lay claim to knowing "all things" (i.e., the whole universe, or even its infinite "areas of discourse")? But for one disgruntled underground species of philosopher who can't quite give up that grandiose aspiration, the study of Hegel allows him to do something of this sort, and with a certain amount of respectability, and without having to put on airs of being a genius. (Oh yes, some will consider this sort of philosopher eccentric and perhaps not invite them to soirees or to give papers, but they will be tolerated, and perhaps even be sought after as token reminders of a vanishing species.

But the most serious and important impetus to the study of Hegel, in my opinion, is an instinctive and/or self-conscious interest in metaphilosophy. "Metaphilosophy" in the comtemporary world has four distinguishable connotations: It can mean 1) the study of the nature of philosophy; or 2) the comparison of one philosophical school with another with regard to various perspectives or points of doctrine; or 3 ) the enterprise of determining the structural interrelationship of the various positions and schools in philosophy, so that they can be comprehended in their totality; or 4) the study of philosophical discourse (and for those for whom "philosophy" is equivalent to the study of discourse, "metaphilosophy" becomes the study of [philosophical] discourse about discourse). The study of Hegel seems to be relevant to metaphilosophy especially in the first and third sense of the term. As regards the first sense, Hegel was acutely aware of the fact that "buck-passing" must stop with philosophy, that if philosophy does not become self-consciously aware of its methodology and presuppositions it can depend on no other higher discipline to inculcate that self-consciousness, and it is precisely the critical self-consciousness of the philosopher that in Hegel's estimation supplies the dialectical impetus out of provincial and incomplete positions towards "Absolute Knowledge" the state at which philosophy becomes fully self-conscious. As regards the third sense of "metaphilosophy", one of Hegel's most persistent endeavors was to develop a comprehensive "System" of philosophy in which all the various schools of thought - empiricism and idealism, materialism and rationalism, as well as Platonism, Cartesianism, Kantianism, etc. - could be seen in their proper perspective and interrelationships. Needless to say, Hegel was an incorrigible optimist about the possibility of finding a place for even the strangest bedfellows; and in our day, as we make our way through the intellectual wilds of ethical noncognitivism, process philosophy and its finite God, existential Marxists, Marxist theologians, and secondand third-order linguistic analysts - we could no doubt use a good dose of Hegel's optimism about the possibility of synthesis.

So much for the possible subjective instigations or motivations for the renewal of interest in Hegel. I would like in the remainder of this paper to discuss some of the objective results of the intensified study of Hegel, and then to close with a critical assessment of Hegel's deficiencies and errors.

One salutary result of the study of Hegel had been its inducement to a holistic view. One cannot read Hegel seriously and sympathetically without beginning to view the 
specialization and prima facie autonomy of various branches of philosophy as a situation lacking necessity (ontological or otherwise) and even counter-productive. To Hegel's mind, metaphysics must be studied in conjunction with epistemology and logic; ethics in conjunction with politics, philosophical anthropology, law; and so forth. We do not necessarily have to agree with Hegel that the holistic approach is the "only" viable one; but we would no doubt benefit from complementing the process of specialization with a process of integration, analysis with synthesis. ${ }^{8}$

One result of the study of Hegel's political philosophy has been a critical reassessment of democratic ideology. ${ }^{9}$ Hegel was in harmony with liberal democratic theory in his emphasis on citizen participation in government; but he was sharply at odds with the democratic theorists regarding the mode of participation in government. Hegel had no patience with the idea that "one man, one vote" was a formula guaranteeing political self-determination. He insisted on the fact that the "input" of the citizenry should be mediated by natural groupings, e.g. labor unions as well as industrial interests, and that government should be highly structured to assure that representation from all the various natural or organic groupings in the state will find a place in the national assemblies. At a time when the election of Hitler on the basis of the "one man, one vote" principle is still a fairly recent memory, and when the control of the average American working man over the federal government is often reducible to perilous choices, every few years, between congressional or presidential candidates neither of whom is thought satisfactory -- it would be appropriate for us to ask, like Hegel, is there any ingenuous, natural way to insure constant participation and representation of citizens in a free state?

In metaphysics and ethics one very important consequence of Hegel's dialectical approach is an emphasis on paradox. To most Western philosophers, paradox is something found exclusively in poetry, Eastern philosophy and the Christian gospels; and a paradox in philosophy is something to be avoided, perhaps studied, but certainly not to be intentionally cultivated. Hegel's philosophy, in contrast, is replete with paradoxes, deliberately produced and not infrequently proffered as a kind of solution rather than as a "problem" or puzzle. For example, we find that the Master is the Slave, and vice versa; that sense certainty is the most "abstract" form of knowledge; that the moralist must unconsciously perpetuate immorality to safeguard his principles; that established communal possession of property (communism) would destroy both property and personality; that being and nothingness as ultimate abstractions converge in meaning; that freedom is at its highest level when it is extrinsically established and necessitated; and that our consciousness of God is identical with God's consciousness of himself. The existence of paradoxes, of course, puts to the test our linguistic

\footnotetext{
${ }^{8}$ I have made an attempt in that direction in a forthcoming book Ethica Dialectica: a Study of Ethical Oppositions (Nijhoff, 1978), which includes chapters on morality and legality, ethics and politics, ethics and aesthetics, etc.

${ }^{9}$ E.g. in Judith Shklar's book, mentioned above, n. 2.
} 
and logical conventions regarding univocity and non-contradiction, but to dismiss them simply on such grounds would be analogous to Einstein dismissing phenomenon such as apparent change of mass at high speeds, because they flouted Newtonian physical laws. In other words, it may just so happen that there are some philosophical truths that can only be stated paradoxically, and not after the manner of a scientific proposition.

I would like to suggest that one final consequence of the Hegel "renaissance" would have to be a revival of Christian philosophy. I realize that leftist and atheist Hegelians still abound, but anyone who studies the life and intellectual evolution of Hegel must realize that his abandonment of the ministry after receiving his theology degree was not a signal that he was abandoning faith and commitment to Lutheran Christianity. It is true that, because of his confidence in the power of Reason, Hegel seems to some to make short shrift of faith, and even to tend towards a sort of Gnosticism. But one must understand that Hegel took Anselm's dictum "fides quaerens intellectum" (faith seeking understanding) even more seriously than Anselm himself. For example, in the Introduction to his Philosophy of History, Hegel poses the rhetorical question, why is it that Christians seem so loathe to obey the great commandment "to love and know the Lord"? ${ }^{10}$ Why are they so diffident about being able to know the Lord, when they are commanded to do so by God himself? In particular (with regard to the philosophy of history) why do they take refuge in "faith" in Divine Providence, as if it were impossible to come to a scientific understanding of the way that Divine Providence unfolds in and through history? And thus, although Hegel is taken as the progenitor of the secularization hypothesis and even the "death of God" movement, Hegel is more properly the apologist for the presence of God in the world (for example, his Philosophy of History is expressly a justification of the way that Divine Providence is leading mankind to freedom). But the fact that Hegel's God is a worldly God has scandalized some Christian philosophers, and of course it is only those others who can believe in a God of this sort who will find in Hegel a source of Christian philosophy.

Let me now balance this perusal of the positive aspects of Hegelianism with an appraisal of some of the more salient deficiencies and errors of Hegel.

Many critics of Hegel, including Marx and Kierkegaard, have pointed out that Hegel's "System" was a magnificent failure while admitting that his dialectical "method" was a great achievement. Others exonerate the System from guilt, and point to the dialectic itself as Hegel's drawback. ${ }^{11}$ I side with the former critics. Hegel's System is obviously patterned after Fichte's and Schelling's attempts at system-building, and is thus "dated" and only of historical interest to those outside Hegel's cultural context. However, I would add the observation that those who oppose systems -- whether political or philosophical -- must do so systematically to be effective.

\footnotetext{
${ }^{10}$ Sibree tr., p. 14

${ }^{11} \mathrm{Cf}$. for example, Werner Becker, Hegel's Phanomenologie des Geistes: eine Interpretation (Stuttgart, 1971$)$, p. 140. Becker, a realist, claims that dialectic in the last analysis is an anti-progressive (conservative) methodology.
} 
There seems to be something instinctive about human system-building. Kierkegaard could never have been an effective antagonist of Hegel without his own counter-system.

Hegel, influenced by his own cultural milieu, was also subject to some very deep-seated prejudices, and we should be aware of these in studying him. For one thing, in line with the proHellenist sentiment of the times he grew up in, he lionized the Greeks, but saw fit to characterize the Roman Republic and the Roman Empire as essentially a band of robbers who got together and required some strong practical laws and tyrannical control to keep them from turning on each other ${ }^{12}$ (as if they were some ancient version of the Mafia). And although one could interpret parts of Hegel's chapter on "Faith and Insight" in the Phenomenology as a defense of Catholic veneration of relics, crucifixes and the host, nevertheless when Hegel speaks explicitly in his Philosophy of History and Philosophy of Religion about Catholicism, he almost always refers to it with extreme Lutheran bias as an example of superstition and brainwashing, and as the main obstacle to man's attainment of freedom in the modern world.

The provinciality of Hegel likewise seems remarkable, if we consider the fact that he was the great exponent of Absolute Spirit in its universality. In his Philosophy of History, Hegel not only "writes off" China as being outside history, but refuses to even devote any attention to Russia and the Slavic countries because they had not contributed anything important to past (European) history. And even Hegel's empathy with fellow European nations was severely limited, as is witnessed by his disagreement with Kant about the possibility of anything like a League of Nations. ${ }^{13}$ Hegel, like Kant, ${ }^{14}$ seemed to think of the Negroes as a definitely inferior race, exhibiting "the natural man in his completely wild and untamed state." 15 In line with these sentiments he of course eliminates the whole continent of Africa from explicit historical consideration, except in so far as they were influenced by European Mediterranean culture. He offers a left-handed compliment to "the Negroes", however, insofar as he ascribes natural talent to them, whereas the American Indians, he opines, have no such natural endowments! ${ }^{16}$

Hegel's praise of war and overall militarianism are well-known. But actually, such sentiments are surprising if we take into account the fact that there is at least an implicit realization of what is in modern parlance called "sublimation" in Hegel's philosophy. If, for example, the "Life and Death Struggle" 17 is sublated (aufgehoben) or "sublimated" into a Master-Slave relationship, and if the latter in its turn is sublated or sublimated into Stoicism, etc. - why cannot the propensity to war itself be sublated or sublimated into some higher form? Much has already been said in criticism of Hegel's defense of monarchy. So I will not dwell on this subject except to point out that his defense of monarchy itself seems to be

\footnotetext{
${ }^{12}$ See Philosophy of History, p. 283ff., p. 431.

${ }^{13}$ See Philosophy of Right, 333, Remark.

${ }^{14}$ See e.g. Observations on the Feeling of the Beautiful and Sublime. Goldthwart tr. (Berkeley, 1960, p. 110.

${ }^{15}$ Philosophy of History, p. 93.

${ }^{16}$ Philosophy of History, p. 82.

${ }^{17}$ Phenomenology, Miller tr., 187
} 
indicative of a deeper philosophical deficiency in Hegel - an overemphasis on idealistic formalism (i.e. the sort for which Hegel criticized Fichte). For Hegel's defense of the monarch in the Philosophy of Right is dictated by the necessity of finding an adequate synthesis of nature and spirit. From the point of view of the exigencies of this synthesis, the monarch was almost a god-sent gift to philosophy. For the monarch was a leader by birth, i.e. nature, and also the epitome of freedom, individuality and uniqueness - i.e. the qualities of spirit. But Hegel's joy in finding such a perfect synthesis seems to have been dampened by the realization that this idea conflicted with empirical reality. ${ }^{18}$ Nevertheless, the Hegel who criticized Fichte so severely in his History of Philosophy for failing to take cognizance of empirical reality seems to fall into the same idealistic "trap".

I would like to conclude this article by posing the question Benedetto Croce posed at the end of the aforementioned book: Should we be Hegelians today? And, like Croce, I would like to answer, "yes and no". No, because the sort of deficiencies I have just mentioned are a formidable obstacle to presenting Hegel's philosophy as the philosophy for our times; and I'm sure that Hegel himself, who strongly insisted on historical and cultural limitations of any philosophy, would not be a "Hegelian" now, if by "Hegelian" is meant someone who champions monarchy, systems built out of triads, ${ }^{19}$ outdated scientific ideas, etc. but yes, we should be "Hegelians" if by "Hegelian" is meant for example, someone who gives explicit attention to the dialectical oppositions in the contemporary spirit and tries to bridge these oppositions on a philosophical level, or someone who sees the subiect-object relationship as a fundamental

\footnotetext{
${ }^{18}$ See Philosophy of Right, 171, Zusatze, in which Hegel admits that the effective power of the monarch is to be limited to "dotting the i's and crossing the t's". Some have suggested that passages such as this, along with other passages that extoll trial by jury and advance forms of legislative representation (neither of which were featured in Prussia at the time Hegel wrote the Philosophy of Right), have to be taken as examples of supreme and intentional irony. In other words, Hegel in writing such things was actually rebelling against the status quo - as much as a writer could rebel in those times without being censored or ejected as a revolutionary.

As added confirmation of this thesis they draw attention to the fact that Hegel seems to reverse the usual order of the Encyclopedia and proceed from the concrete (the monarch) to the abstract (legislative and executive) rather than the reverse (which would seem more "normal").

However, this thesis must deal with the following objections: 1) there is an obvious parallel between the procedure here and that found in the section on the Family, in which Hegel proceeds from the individual to the family, and civil society, i.e. to the larger context; 2) if Hegel did not prefer a limited monarchy, what did he prefer? and how do we explain his fairly frequent criticisms of democracy and republican forms of government? and 3) it would be more proper to say that the Philosophy of Right is about the Idea of the State, rather than the State itself and it is possible and even probable that certain progressive aspects of the free State (e.g. trial by jury) might be quite clearly implicated in the Idea of the State, although they have not yet been instantiated in empirical reality (Hegel maintained not only that "the Real is the Rational" but also that "the Rational is the Real").

${ }^{19}$ I am not referring here to the use of dialectic, but to the explicit presentation of systems triadically. This latter propensity seems to be something peculiar to early 19th century idealism, which was elated to have "rediscovered" "triplicity". This propensity is analogous to the enthusiasm of certain mediaeval scholastics who "rediscovered" Aristotelian syllogistic laws and tried to organize treatises explicitly in syllogistic form. However, the traditional philosopher can never dispense with syllogisms, and the dialectical philosopher cannot dispense with the process of opposition and synthesis. It should be noted that the Phenomenology as a kind of "voyage of discovery" is less overtly structured triadically - and, strange as it may seem, this may be one reason why the Phenomenology seems less "foreign" to 20th century philosophers than the System proper.
} 
philosophical problematic worthy of serious attention and hard work, or someone who is concerned with assuring meaningful and effective participation of citizens in their government. And I might add that I'm sure that one of the best ways of becoming a "Hegelian" in the latter sense is to study Hegel. 